\title{
PENGARUH TINGKAT UPAH DAN NILAI OUTPUT TERHADAP PENYERAPAN TENAGA KERJA INDUSTRI SKALA BESAR DAN SEDANG DI INDONESIA TAHUN 2000 - 2013
}

\author{
Annisa Nurulaini \\ Fakultas Ekonomi, Universitas Negeri Jakarta \\ annisanuralaini@gmail.com \\ Suparno \\ Fakultas Ekonomi, Universitas Negeri Jakarta \\ suparno@unj.ac.id \\ Sri Endah Nikensari \\ Fakultas Ekonomi, Universitas Negeri Jakarta \\ sriendahnikensari@gmail.com
}

\begin{abstract}
This research aims to find out whether wage rates and value of output have effect on job absorption in large and medium scale industry Indonesia 2000-2013. The research method used is time series data from year 2000-2013 and cross section data 6 sub sector using ex post facto approach. The data presented obtainedfrom Central Statistics Agency. This research uses panel data regression model obtained from random effectLnPTK equation $=14,20230-0,306130 \mathrm{LnUPAH}+0,331084$ LnOUTPUT. Based on the results of the regression analysis partially known that the wage rates have negative and significant impact on job absorption in large and medium scale industry. Meanwhile the value of output have positive and significant impact on job absorption in large and medium scale industry. Based on the results of the regression analysis simultaneously, wage rates and the value of output together have impact on job absorption in large and medium scale industry. Variation of the influence of independent variables could be determined based on the value of $R^{2} 0.46$. So it can be stated that 46 percent variation of the job absorption in large and medium scale industry influenced by wage rates and the value of output.
\end{abstract}

Keywords: wage rates, the value of output and job absorption 


\section{PENDAHULUAN}

Pembangunan ekonomi adalah hal yang sangat penting dalam suatu negara, terutama dalam meningkatkan pertumbuhan ekonomi dan meningkatkan kesejahteraan rakyatnya. Pembangunan ekonomi yang mampu dicapai oleh suatu negara tidak terlepas dari sistem ekonomi yang diterapkan. Sistem ekonomi yang baik mampu membuat kegiatan ekonomi suatu negara berjalan sesuai dengan rencana dan terarah. Setiap negara pasti memiliki sistem perekonomiannya sendiri. Begitu pula dengan Indonesia dengan sistem ekonomi pancasilanya. Selain sistem ekonomi, struktur ekonomi
Indonesia yang mengalami perubahan juga membawa dampak terhadap kegiatan ekonomi.

Pada awal setelah kemerdekaan, struktur ekonomi Indonesia bersifat agraris. Namun kini struktur ekonomi Indonesia bersifat dualistis yaitu mata pencarian utama sebagian besar penduduknya pada sektor pertanian yang berarti struktur perekonomian masih agraris. Tetapi penyumbang utama pada pendapatan nasional adalah sektor industri pengolahan, yang berarti struktur perekonomian industri. Dengan demikian struktur perekonomian Indonesia mulai bergeser dari agraris menjadi industri.

Tabel I.1

Produk Domestik Bruto Atas Dasar Harga Berlaku Menurut LapanganUsaha (Miliar Rupiah)

\begin{tabular}{|c|c|c|c|c|}
\hline \multirow{2}{*}{ No } & \multirow{2}{*}{ Lapangan Usaha } & \multicolumn{3}{|c|}{ Tahun } \\
\hline & & 2011 & 2013 & 2014 \\
\hline 1 & $\begin{array}{l}\text { Pertanian, Peternakan, } \\
\text { Kehutanan dan Perikanan }\end{array}$ & $1.091 .447,11.193 .452,9$ & $1.310 .427,3$ & $1.446 .722,3$ \\
\hline 2 & $\begin{array}{l}\text { Pertambangan dan } \\
\text { Penggalian }\end{array}$ & $876.983,8 \quad 972.458,4$ & 1.026 .297 & $1.058 .750,2$ \\
\hline 3 & $\begin{array}{l}\text { Industri } \\
\text { Pengolahan }\end{array}$ & $1.806 .140,51.972 .523,6$ & $2.152 .802,8$ & $2.394 .004,9$ \\
\hline 4 & $\begin{array}{l}\text { Listrik, Gas dan } \\
\text { Air Bersih }\end{array}$ & $62.271,6$ & $70.339,6$ & 81.131 \\
\hline 5 & Bangunan & $753.554,6 \quad 844.090,9$ & 907.267 & $1.014 .540,8$ \\
\hline 6 & $\begin{array}{l}\text { Perdagangan, } \\
\text { Hotel dan } \\
\text { Restoran }\end{array}$ & $1.023 .724,8 \quad 1.148 .791$ & 1.301 .175 & $1.473 .559,7$ \\
\hline 7 & $\begin{array}{l}\text { Pengangkutan dan } \\
\text { Komunikasi }\end{array}$ & $491.287 \quad 549.105,4$ & $635.302,9$ & $745.648,2$ \\
\hline 8 & $\begin{array}{l}\text { Keuangan, Persewaan dan } \\
\text { Jasa Perusahaan }\end{array}$ & $\begin{array}{l}535.152,9 \\
598.433,3\end{array}$ & $682.973,2$ & $771.961,5$ \\
\hline 9 & Jasa-Jasa & $\begin{array}{ll}785.014,1 \quad 889.798,8 \\
\end{array}$ & $1.000 .691,7$ & $1.108 .610,3$ \\
\hline
\end{tabular}

Berdasarkan data pada tabel diatas jumlah Produk Domestik Bruto pada setiap sektor cenderung meningkat setiap tahun. Namun sektor industri pengolahan menghasilkan jumlah yang paling banyak diantara yang lainnya. Hal ini menunjukkan bahwa struktur perekonomian Indonesia mulai beralih 
menjadi industri dilihat dari sumbangannya terhadap PDB.

Sektor yang menjadi fokus pada penelitian ini adalah sektor industri pengolahan skala sedang dan besar. Industri pengolahan sedang dan besar merupakan salah satu industri yang menyerap tenaga kerja yang cukup besar sehingga penerapannya sangat cocok di Indonesia yang membutuhkan industri teknologi padat karya guna mengurangi tingkat pengangguran. Badan Pusat Statistik (BPS) melaporkan bahwa industri manufaktur Indonesia skala sedang dan besar mencetak pertumbuhan 9\% sepanjang tahun 2012 dibandingkan setahun sebelumnya. Selama empat tahun terakhir, jumlah industri pengolahan skala sedang dan besar terus mengalami peningkatan. Peningkatan terbesar terjadi pada tahun 2013 yaitu sebesar $14 \%$.

Tabel 1.2

Jumlah Industri Pengolahan Sedang dan Besar di Jawa dan Luar Jawa

(Unit)

\begin{tabular}{|c|c|c|c|}
\hline \multirow{2}{*}{ Tahun } & \multicolumn{2}{|c|}{ Lokasi } & \multirow{2}{*}{ Jumlah } \\
\hline & Jawa & Luar Jawa & \\
\hline 2010 & 19.529 & 3.816 & 23.345 \\
\hline 2011 & 19.440 & 3.930 & 23.370 \\
\hline 2012 & 19.554 & 4.038 & 23.592 \\
\hline 2013 & 19.773 & 4.168 & 23.941 \\
\hline
\end{tabular}

Sumber: Badan Pusat Statistik.

Berdasarkan tabel tersebut dapat dilihat bahwa industri sedang dan besar lebih banyak berada di Pulau Jawa karena Pulau Jawa lebih mendukung dibandingkan luar Pulau Jawa. Hal ini sesuai dengan yang diungkapkan oleh Dirjen Pengembangan Pewilayahan Industri Kemenperin Dedi Mulyadi bahwa dari sisi sumber daya manusia, infrastruktur, dan sumber daya alam, Pulau Jawa lebih siap menjadi lokasi pengembangan industri dibandingkan dengan pulau-pulau lainnya .

Sekretaris Jenderal Kemenperin Anshari Bukhari menyatakan, pemerintah berambisi menambah populasi industri skala sedang dan besar di dalam negeri sekitar 9 ribu unit dalam lima tahun mendatang. Sehingga ke depannya sektor industri sedang dan besar mampu menyerap tenaga kerja lebih banyak lagi dan angka pengangguran pun semakin berkurang.

Tabel I.3

Kontribusi Industri Sedang dan Besar Terhadap PDB Nasional 2010-2013

\begin{tabular}{cccr}
\hline Tahun & PDB Nasional & Nilai Output ISB & Kontribusi \\
\hline 2010 & $R p$ 6.864.133,1 miliar & $R p 2.208 .330$ miliar & $32,17 \%$ \\
\hline 2011 & $R p 7.287 .635,3$ miliar & $R p 2.618 .050$ miliar & $35,92 \%$ \\
\hline 2012 & $R p 7.727 .083,4$ miliar & $R p 2.869 .622$ miliar & $37,13 \%$ \\
\hline 2013 & $R p 8.158 .193,7$ miliar & $R p 2.997 .617$ miliar & $36,74 \%$ \\
\hline
\end{tabular}

Sumber: Badan Pusat Statistik, diolah.

Berdasarkan tabel tersebut dapat dilihat bahwa selama empat tahun terakhir kontribusi industri skala sedang dan besar cenderung meningkat. Peningkatan terbesar terjadi pada tahun 2011 yaitu sebesar $3,75 \%$. 
Sedangkan untuk nilai output industri skala mikro dan kecil, selalu ada peningkatan setiap tahunnya, begitur pula dengan persentase kontribusi industri mikro dan kecil terhadap PDB Nasional. Peningkatan terbesar terjadi pada tahun 2011 yaitu sebesar 9,6\%. Jika dibandingkan dengan sektor industri mikro dan kecil pada Tabel I.4, industri skala sedang dan besar memang lebih sedikit dalam berkontribusi terhadap nilai PDB nasional.

Industri skala sedang dan besar pada penelitian ini difokuskan lagi hanya kepada enam subsektor yang termasuk ke dalam sub sektor industri padat karya, yaitu subsektor makanan dan minuman, pengolahan tembakau, tekstil, pakaian jadi, kulit dan alas kaki dan susbektor kayu, gabus dan anyaman dari bambu, rotan dan sejenisnya.

Industri padat karya merupakan sektor yang berperan besar dalam menyerap tenaga kerja, memenuhi kebutuhan dalam negeri serta menambah devisa melalui kegiatan ekspor. Dengan demikian industri padat karya merupakan industri yang diprioritaskan oleh pemerintah. Karena sebagian besar penduduk Indonesia atau sekitar 66 persen dari jumlah penduduk hanya lulusan Sekolah Dasar (SD) dan Sekolah Menengah Pertama (SMP). Dengan adanya industri padat karya yang dapat menyerap angkatan kerja dengan tingkat pendidikan dasar dan menengah tersebut, maka pemerintah dapat menekan angka pengangguran.

Prioritas pembangunan industri di Indonesia adalah yang berpihak pada rakyat banyak. Contohnya adalah industri garmen dan alas kaki . Dengan demikian pemerintah terus melakukan upaya-upaya untuk meningkatkan peran industri padat karya sebagai penopang perekonomian rakyat. Upaya yang dilakukan pemerintah untuk mengembangkan industri ini adalah dengan melakukan deregulasi dan pembangunan infrastruktur. Banyaknya peraturan mengenai perizinan ataupun hal lainnya terkait pengembangan industri padat karya selama ini menjadi salah satu penghambat dalam menghadapi persaingan ekonomi global. Oleh karena itu pemerintah melakukan deregulasi yang juga akan berdampak kepada kelancaran pembangunan infrastruktur untuk menunjang pembangunan kawasan industri.

Selain ke dua hal tersebut, investasi juga sangat diperlukan untuk membangun industri padat karya. Seperti yang dikatakan oleh Kepala Badan Koordinasi Penanaman Modal (BKPM) Franky Sibarani bahwa investasi industri padat karya masih menjadi prioritas pemerintah . Untuk itu, BKPM fokus mendorong investasi masuk ke sektor tersebut termasuk mengatasi kendalakendala investasi.

Sektor industri skala sedang dan besar khususnya industri padat karya mampu menyerap banyak tenaga kerja karena dikerjakan oleh banyak tenaga manusia. Oleh karena itu, perkembangan industri ini menjadi salah satu tumpuan bagi terserapnya angkatan kerja yang belum bekerja dan yang menganggur. Dari ke enam sub sektor yang menjadi fokus pada penelitian ini hingga tahun 2013 yang paling banyak menyerap tenaga kerja adalah sub sektor makanan dan minuman yaitu menyerap sebesar 877.424 jiwa dan yang paling sedikit menyerap tenaga kerja adalah subsektor kulit, barang dari kulit dan alas kaki yaitu sebesar 220.723 jiwa. 
Tabel I.5

Jumlah Tenaga Kerja Industri Sedang dan Besar Menurut Sub Sektor

\begin{tabular}{|c|c|c|c|c|}
\hline \multirow{2}{*}{ Subsektor } & \multicolumn{4}{|c|}{ Tahun } \\
\hline & 2010 & 2011 & 2012 & 2013 \\
\hline Makanan dan Minuman & 714.711 & 785.462 & 931.293 & 877.424 \\
\hline $\begin{array}{l}\text { Pengolahan } \\
\text { Tembakau }\end{array}$ & 329.877 & 304.243 & 324.614 & 278.953 \\
\hline$\overline{\text { Tekstil }}$ & 482.963 & 477.387 & 482.349 & 427.083 \\
\hline Pakaian Jadi & 528.579 & 561.908 & 600.109 & 473.594 \\
\hline $\begin{array}{l}\text { Kulit, Barang dari Kulit dan } \\
\text { Alas } \\
\text { Kaki }\end{array}$ & 234.173 & 247.426 & 256.500 & 220.723 \\
\hline $\begin{array}{l}\text { Kayu, Gabus dan Anyaman } \\
\text { dari Bambu, Rotan }\end{array}$ & 221.226 & 212.313 & 225.456 & 221.132 \\
\hline
\end{tabular}

Data pada tabel diatas dengan tahun sebelumnya.

menunjukkan bahwa jumlah tenaga kerja Penyerapan tenaga kerja sektor industri besar dan sedang secara industri sedang dan besar yang fluktuatif keseluruhan mengalami perkembangan dapat dibandingkan dengan jumlah yang fluktuatif. Bahkan pada tahun 2013 pengangguran. Jika jumlah pengangguran setiap sub sektor mengalami penurunan besar maka dapat disimpulkan bahwa jumlah tenaga kerja yang terserap. angkatan kerja yang terserap pada sektor Penurunan jumlah tenaga kerja yang industri sedang dan besar pun sedikit terbesar adalah pada sub sektor pakaian karena lebih banyak orang yang jadi, yaitu sebesar $21,08 \%$ atau sebesar 126.515 jiwa lebih sedikit dibandingkan

Tabel 1.6

Jumlah Angkatan Kerja, Penduduk Bekerja dan Pengangguran

\begin{tabular}{cccc}
$\begin{array}{c}\text { (Juta Jiwa) } \\
\text { Tahun }\end{array}$ & Jumlah Angkatan Kerja & $\begin{array}{c}\text { Penduduk } \\
\text { Bekerja }\end{array}$ & Pengangguran \\
\hline 2009 & 113,83 & 104,87 & 8,96 \\
\hline 2010 & 116,53 & 108,21 & 8,32 \\
\hline 2011 & 117,37 & 109,67 & 7,7 \\
\hline 2012 & 118,05 & 110,81 & 7,24 \\
\hline 2013 & 118,19 & 110,8 & 7,39 \\
\hline
\end{tabular}

Sumber: Badan Pusat Statistik 
Berdasarkan data pada tabel diatas jumlah angkatan kerja meningkat setiap tahunnya. Kenaikan jumlah angkatan kerja yang paling besar terjadi pada tahun 2010 yaitu sebesar 116,53 juta jiwa dari sebelumnya sebesar 113,83 juta jiwa. Seiring dengan meningkatnya jumlah angkatan kerja, jumlah penduduk bekerja pun semakin meningkat namun lapangan kerja yang tersedia tidak mampu menyerap semua angkatan kerja. Oleh karena itu penurunan jumlah pengangguran tidak signifikan. Bahkan di tahun 2013 jumlah pengangguran meningkat sebesar 150.000 jiwa jika dibandingkan dengan tahun 2012.

Pada dasarnya terdapat banyak faktor yang mempengaruhi penyerapan tenaga kerja di sektor industri sedang dan besar diantaranya adalah nilai output, investasi dan jumlah unit usaha. Selain itu dipengaruhi juga oleh pertumbuhan ekonomi dan tingkat upah .

Faktor pertama yang mempengaruhi penyerapan tenaga kerja adalah nilai output. Nilai output atau hasil produksi ini merupakan permintaan akan hasil produksi dari sebuah proses produksi. Sehingga apabila jumlah permintaan akan hasil produksi besar maka dengan sendirinya akan meningkatkan jumlah tenaga kerja yang dipekerjakan. Karena jumlah tenaga kerja merupakan faktor permintaan turunan dari jumlah permintaan akan produk hasil produksi.

Sesuai dengan penjelasan pada teori ekonomi mikro, nilai produksi merupakan faktor yang signifikan dalam mempengaruhi penyerapan tenaga kerja. Sehingga apabila jumlah permintaan akan hasil suatu produksi mengalami kenaikan, maka jumlah pekerja dari kegiatan produksi tersebut juga akan meningkat sesuai dengan peningkatan jumlah produksinya.

Faktor kedua yang berpengaruh terhadap penyerapan tenaga kerja sektor industri sedang dan besar adalah tingkat upah. Dalam memproduksi output barang dan jasa yang diperlukan, perusahaan akan membutuhkan faktor-faktor produksi seperti tenaga kerja. Sedangkan upah merupakan salah satu biaya produksi yang harus dikeluarkan perusahaan.

Tingkat upah pada ke enam sub sektor industri skala sedang dan besar yang menjadi fokus penelitian cenderung meningkat setiap tahunnya. Hal ini terjadi sebagai dampak dari kenaikan upah minimum setiap provinsi yang didasarkan pada kebutuhan hidup layak. Tujuan pemerintah menerapkan upah minimum ini adalah untuk melindungi pekerja atau buruh dari perlakuan pengusaha yang kurang memperhatikan kesejahteraannya.

Kenaikan upah tenaga kerja mengakibatkan biaya produksi industri dalam negeri menjadi lebih tinggi dan tidak kompetitif dibanding negara lain . Biaya produksi yang tinggi tersebut menyebabkan harga barang yang dihasilkan pun mahal dan tidak kompetitif di pasaran bahkan lebih mahal daripada produk impor. Sehingga dengan kalah saingnya produk industri dalam negeri dibandingkan dengan produk impor menjadikan banyak orang berfikir lebih memilih untuk melakukan impor dibandingkan dengan mendirikan industri. 


\section{KAJIAN PUSTAKA}

Hinsa Sahaan yang mengatakan bahwa, industri adalah bagian dari suatu proses yang mengelolah bahan mentah menjadi bahan baku atau bahan baku menjadi barang jadi, sehingga menjadi suatu barang yang memiliki nilai bagi masyarakat luas.

Definisi industri menurut Suyadi Prawisentono yaitu industri merupakan kelompok perusahaan yang mempunyai kegiatan sejenis baik secara vertikal maupun horizontal.

Menurut Eko Tri, tenaga kerja adalah penduduk yang dapat bekerja dan sanggup bekerja jika ada permintaan. Menurut UU Ketenagakerjaan Pasal 1 ayat 2 UU No. 13 Tahun 2003, tenaga kerja adalah setiap orang yang mampu melakukan pekerjaan baik di dalam maupun diluar hubungan kerja, guna menghasilkan barang atau jasa untuk memenuhi kebutuhan hidup sendiri maupun masyarakat.

Menurut Nurimansyah Hasibuan, upah adalah segala macam bentuk penghasilan yang diterima oleh buruh atau pegawai (tenaga kerja) baik berupa uang atau barang dalam jangka waktu tertentu pada suatu kegiatan ekonomi. Menurut Imam Soepomo upah adalah pembayaran yang diterima buruh selama ia melakukan pekerjaan.

F. Winarni dan G. Sugiyarso mendefinisikan bahwa upah adalah suatu penerimaan sebagai imbalan dari pemberi kerja kepada penerima kerja termasuk tunjangan, baik untuk pekerja sendiri maupun keluarganya(Winarni, 2008).

Paul A. Samuelson dan William D. Nordhaus dalam bukunya menyatakan bahwa output adalah berbagai barang dan jasa yang berguna yang dihasilkan dari proses produksi untuk konsumsi atau digunakan dalam proses produksi selanjutnya(Samuelson, 2004).

Tingkat output ini diukur melalui salah satu pendapatan nasional yang disebut Gross Domestic Product (GDP). GDP merupakan penghitungan yang digunakan oleh suatu negara sebagai ukuran utama bagi aktivitas perekonomian nasionalnya, tetapi pada dasarnya GDP mengukur seluruh volume produksi dari suatu wilayah (negara) secara geografis.

Menurut McEachern, GDP artinya mengukur nilai pasar dari barang dan jasa akhir yang diproduksi oleh sumber daya yang berada dalam suatu negara selama jangka waktu tertentu, biasanya satu tahun. GDP juga dapat digunakan untuk mempelajari perekonomian dari waktu ke waktu atau untuk membandingkan beberapa perekonomian pada suatu saat.

Menurut Budiono, pasar tenaga kerja hanyalah mengikuti apa yang terjadi di pasar barang. Apabila output yang diproduksi naik, maka jumlah orang yang dipekerjakan juga naik

\section{METODOLOGI PENELITIAN}

Metode penelitian yang digunakan dalam penelitian ini adalah Ekspos Facto dengan pendekatan korelasional. Metode ini dipilih karena sesuai untuk mendapatkan informasi yang bersangkutan dengan status gejala pada saat penelitian dilakukan. Pendekatan korelasional yang dilakukan adalah dengan menggunakan korelasi ganda. Korelasi ganda dipilih karena dapat menunjukkan arah pengaruh faktor-faktor penentu (tingkat upah dan nilai output) terhadap penyerapan tenaga kerja industri besar dan sedang dalam penelitian ini. 
Dalam penelitian ini terdapat tiga variabel yang menjadi objek penelitian dimana penyerapan tenaga kerja industri skala sedang dan besar merupakan variabel terikat (Y), sedangkan variabel bebas adalah tingkat upah (X1) dan nilai output (X2). Konstelasi pengaruh antar variabel di atas dapat digambarkan sebagai berikut:

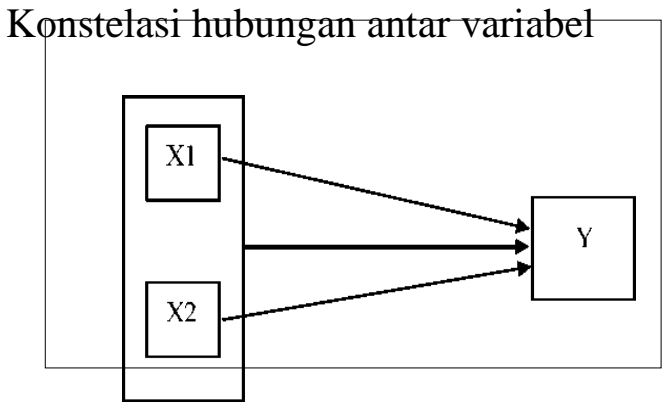

Keterangan:

$\mathrm{X} 1=$ Tingkat upah (variabel bebas)

$\mathrm{X} 2=$ Nilai output (variabel bebas)

$\mathrm{Y} \quad=$ Penyerapan tenaga kerja industri

sedang dan besar (variabel terikat)

$\rightarrow \quad=$ Arah pengaruh

\section{HASIL DAN PEMBAHASAN}

Berdasarkan tahapan dan perhitungan yang telah dilakukan pada periode waktu tahun 2000 sampai dengan tahun 2013 terhadap penyerapan tenaga kerja industri skala besar dan sedang yang difokuskan pada enam sub sektor industri padat karya di Indonesia untuk mengetahui apakah ada pengaruhnya antara tingkat upah dan nilai output terhadap jumlah angkatan kerja yang terserap pada sektor industri tersebut. Peneliti dalam hal ini menggunakan estimasi model random effect.

Berdasarkan model tersebut maka diperoleh persamaan regresi penelitian sebagai berikut:

LnPTK $=14,20230-0,306130$ LnUPAH + 0,331084LnOUTPUT

Hasil persamaan regresi tersebut memiliki nilai konstanta sebesar 14,20 sehingga dapat diartikan bahwa ketika tingkat upah dan nilai output adalah konstan atau nol, maka jumlah penyerapan tenaga kerja adalah sebesar 14,20 persen. Nilai koefisien tingkat upah adalah $-0,3061$ sehingga dapat diartikan bahwa ketika tingkat upah naik 1 persen dengan asumsi cateris paribus maka jumlah penyerapan tenaga kerja menurun sebesar 30 persen. Variabel selanjutnya adalah nilai output yang memiliki pertumbuhan positif yang apabila meningkat 1 persen dengan asumsi cateris paribus maka akan meningkatkan jumlah penyerapan tenaga kerja sebesar 33 persen.

Berdasarkan uji hipotesis dengan menggunakan uji $\mathrm{t}$ pada tingkat upah terlihat bahwa thitung sebesar -7,439234 lebih besar bila dibandingkan dengan ttabel sebesar 1,66388 yang menunjukkan bahwa terdapat pengaruh yang negatif antara tingkat upah dengan penyerapan tenaga kerja. Hasil tersebut sesuai dengan hipotesis yang telah diajukan oleh peneliti sehingga kondisi yang terjadi ketika tingkat upah tenaga kerja naik, maka jumlah penyerapan tenaga kerja menurun dan begitu pula sebaliknya. Hal tersebut didasarkan bahwa penyerapan tenaga kerja dilihat dari sisi permintaan tenaga kerja. Kurva permintaan tenaga kerja memiliki lereng yang negatif, artinya pada tingkat upah tinggi maka jumlah tenaga kerja yang diminta sedikit. Selain itu menurut Simanjuntak bahwa upah dipandang sebagai suatu beban oleh perusahaan, karena semakin besar tingkat upah maka akan semakin kecil keuntungan yang dinikmati oleh pengusaha. Oleh karena itu kenaikan upah tidak direspon baik oleh pengusaha.

Variabel selanjutnya adalah nilai output yang berdasarkan hasil estimasi model terbaik menunjukkan bahwa nilai output memiliki pengaruh positif dan signifikan terhadap penyerapan tenaga kerja. Koefisien regresi untuk variabel nilai output terhadap penyerapan tenaga kerja bernilai positif yaitu sebesar 0,331084 dan hasil pengujian t hitung maupun $p$-value 
menunjukkan nilai output memiliki pengaruh yang signifikan terhadap penyerapan tenaga kerja. Koefisien tersebut bermakna bahwa setiap kenaikan nilai output sebesar 1 persen dengan asumsi cateris paribus mengakibatkan kenaikan penyerapan tenaga kerja sebesar 33 persen.

Koefisien regresi yang positif berarti kenaikan nilai output akan selaras dengan kenaikan penyerapan tenaga kerja. Semakin besar nilai output maka akan semakin besar pula tenaga kerja yang terserap. Hal ini sesuai dengan teori bahwa pasar tenaga kerja mengikuti apa yang terjadi pada pasar barang. Apabila barang yang diproduksi meningkat maka jumlah orang yang dipekerjakan juga bertambah.

Secara simultan dengan pengujian Fhitung dibandingkan dengan Ftabel diperoleh nilai Fhitung 35,00120 sedangkan Ftabel 3,11. Karena Fhitung lebih besar dibandingkan dengan Ftabel maka dengan tingkat kepercayaan sebesar 95\%, tingkat upah dan nilai output berpengaruh secara bersama-sama terhadap penyerapan tenaga kerja. Sementara itu nilai $\mathrm{R}^{2}$ menunjukkan angka sebesar 0,46 yang berarti variabel tingkat upah dan nilai output dapat menjelaskan variabel penyerapan tenaga kerja sebesar $46 \%$ sedangkan sisanya dipengaruhi oleh variabel-variabel lain diluar penelitian yang dilakukan oleh peneliti.

\section{KESIMPULAN}

Berdasarkan hasil pengolahan datapengaruh tingkat upah dan nilai output terhadap

penyerapan tenaga kerja, maka dapat diambil kesimpulan bahwa:

1. Terdapat pengaruh yang negatif antara variabel tingkat upah terhadap penyerapan tenaga kerja. Hal ini terbukti dengan hasil koefisien regresi sebesar $-0,306130$ dan perhitungan statistik menunjukkan bahwa t hitung lebih besar dari t tabel. Hal tersebut berarti apabila tingkat upah naik maka penyerapan tenaga kerja akan mengalami penurunan.

2. Nilai output memiliki pengaruh terhadap penyerapan tenaga kerja. Jika dilihat dari koefisien nilai output bertanda positif berarti ada pengaruh positif antara nilai output dan penyerapan tenaga kerja. Hal ini terbukti dengan nilai koefisien regresi sebesar 0,331084 dan perhitungan statistik yang menunjukkan bahwa $\mathrm{t}$ hitung lebih besar dari t tabel. Hal tersebut berarti bahwa apabila nilai output meningkat maka penyerapan tenaga kerja akan mengalami peningkatan.

3. Variabel tingkat upah dan nilai output secara simultan berpengaruh terhadap penyerapan tenaga kerja jika dilihat dari koefisien tingkat upah dan nilai output. Hal tersebut dibuktikan dengan perhitungan statistik yang menunjukkan bahwa $\mathrm{F}$ hitung lebih besar dari $\mathrm{F}$ tabel. Dalam penelitian ini nilai koefisien determinasi yang dihasilkan sebesar 0,46 . Artinya variasi dari variabel tingkat upah dan nilai output dapat menjelaskan sebesar $46 \%$ untuk variabel penyerapan tenaga kerja.Dari hasil tersebut disimpulkan bahwa pengaruh kedua variabel bebas cukup pengaruhnya terhadap variabel terikat.

\section{IMPLIKASI}

1. Dari hasil penelitian ini tingkat upah membawa dampak terhadap pengambilan keputusan bagi para pengusaha dalam menyerap tenaga kerja di industri skala sedang dan besar di Indonesia. Ketika terjadi kenaikan tingkat upah maka akan terjadi penurunan jumlah tenaga kerja yang terserap dalam proses produksi. 
Pengaruh negatif antara variabel tingkat upah terhadap penyerapan tenaga kerja membuktikan bahwa pengusaha tidak dapat terus meningkatkan jumlah tenaga kerja seiring dengan kenaikan upah. Hal itu akan membuat biaya produksi semakin meningkat karena biaya yang dikeluarkan untuk tenaga kerja semakin besar.

2. Pengaruh positif antara variabel nilai output terhadap penyerapan tenaga kerja membuktikan bahwa pengusaha pada industri skala besar dan sedang dapat terus menambah jumlah tenaga kerja seiring dengan peningkatan hasil produksi. Ketika terjadi kenaikan jumlah output yang dihasilkan maka akan terjadi peningkatan jumlah tenaga kerja yang dipekerjakan.

3. Tingkat upah dan nilai output secara bersama-sama berpengaruh terhadap penyerapan tenaga kerja berdampak terhadap keputusan pengusaha dalam menambah jumlah tenaga kerja dalam proses produksi. Pengusaha dapat terus menambah jumlah tenaga kerja ketika nilai output produksi semakin bertambah, karena proses produksi memerlukan tenaga kerja yang lebih banyak.

\section{SARAN}

Berdasarkan kesimpulan dan implikasi yang dikemukakan di atas, maka peneliti memberikan beberapa saran sebagai berikut:

1. Kenaikan upah minimum tiap tahunnya di Indonesia dapat memberi dampak positif bagi para pekerja. Namun dalam pelaksanaannya harus tetap diawasi agar peraturan yang telah disepakati bersama antara pemerintah, pengusaha dan tenaga kerja dapat berjalan dengan lebih baik lagi. Sehingga untuk kedepannya dapat membangun industri padat karya yang lebih berkualitas.

2. Dari hasil penelitian dapat dikatakan bahwa dengan nilai output yang tinggi maka akan menambah jumlah tenaga kerja yang dipekerjakan. Namun karena penelitian ini difokuskan pada sub sektor industri padat karya yang membutuhkan banyak tenaga manusia dalam proses produksinya, maka peneliti memberikan saran guna meningkatkan kuantitas output yang dihasilkan serta agar mampu bersaing dengan produk dari luar negeri maka penting untuk mengadakan pelatihan kepada para pekerja. Selain itu industri padat karya harus didukung oleh pemerintah dalam hal penyediaan sarana dan prasarana dan pembukaan pasar ekspor agar produk dalam negeri dapat unggul di pasar internasional dan menarik investor sehingga industri padat karya dapat lebih berkembang.

3. Mengenai tingkat upah dan nilai output yang berpengaruh terhadap penyerapan tenaga kerja maka proses produksi setiap sub sektor industri padat karya harus diperhatikan lagi. Karena dalam praktiknya masih terdapat kesenjangan jumlah tenaga kerja yang terserap antara sub sektor. Hal ini bertujuan agar tidak hanya salah satu sektor saja yang menjadi unggul, melainkan semua sektor dapat menjadi sektor unggulan sehingga dapat menyerap tenaga kerja lebih banyak .

\section{DAFTAR PUSTAKA}

Samuelson, A. P. (2004). IImu Makroekonomi . Jakarta: Media Global Edukasi.

Winarni, d. (2008). Administrasi Gaji dan Upah. Jakarta: PT Bumi Aksara. 